\title{
Surface marker and other characteristics of Gaucher's cells
}

\author{
G. F. BURNS, J. C. CAWLEY, R. J. FLEMANS, K. E. HIGGY, C. P. WORMAN, \\ C. R. BARKER, B. E. ROBERTS, AND F. G. J. HAYHOE \\ From the Department of Haematological Medicine, University of Cambridge and Department of Medicine, \\ University of Leeds, UK
}

SUMMARY A full surface marker study of the splenic storage cells in a case of Gaucher's disease largely substantiates the monocyte/histiocyte nature of Gaucher's cells. In addition, an apparent T-lymphocyte deficiency is demonstrated in the spleen and peripheral blood, and the possible significance of this finding is discussed.

Gaucher's cells have been extensively investigated morphologically and biochemically, and it is now thought that they represent histiocytic cells in which large amounts of glucocerebroside have accumulated because of a deficiency of $\beta$-glucosidase (Brady, 1972). The histiocytic nature of Gaucher's cells has been inferred from their phagocytic ability (Lee et al., 1967), high lysosomal enzyme content (Rozenszajn and Efrati, 1961), and distinctively reticuloendothelial distribution. However, this view has not been universally accepted (Roos et al., 1961; Fisher and Reidbord, 1962) and, in addition, immunological mechanisms have been invoked in the pathogenesis of the disease (Pennelli et al., 1969). Immunological surface marker studies, which have proved of great value in the characterisation of the pathological cells of a wide variety of other haematological proliferations, should therefore contribute to further understanding of the nature of the pathognomonic cells of Gaucher's disease.

No previous surface-marker study of Gaucher's disease has been described, and in the present paper we report such a study in a case of the non-neuronopathic form of the disease.

\section{Patient and methods}

\section{CASE HISTORY}

This 8-year-old girl of Anglo-Saxon descent presented with recurrent epistaxes. Examination revealed massive splenomegaly and moderate hepatomegaly but no other abnormality. The serum acid phosphatase was greatly increased at $17 \cdot 2 \mathrm{KA}$ units, and skeletal

Received for publication 7 March 1977 survey showed early, but definite, Ehrlenmeyer-flask deformity of the femora. There was a peripheral pancytopenia (Hb $10.7 \mathrm{~g} / \mathrm{dl}$, WBC $3.8 \times 10^{9} / \mathrm{l}$, platelets $\left.60 \times 10^{9} / 1\right)$ and differential white count showed $44 \%$ neutrophils, $49 \%$ lymphocytes, and $7 \%$ monocytes. A bone marrow aspirate was hypercellular and contained moderate numbers of typical Gaucher's cells; the cytology and cytochemistry of these are described in detail below. A diagnosis of non-neuropathic Gaucher's disease with hypersplenism was made.

The only other sib, a younger sister aged $5 \frac{1}{2}$ years, also has hepatosplenomegaly with peripheral pancytopenia and high serum acid phosphatase and almost certainly has Gaucher's disease. However, since she is asymptomatic a bone marrow aspirate has not been performed to confirm the diagnosis. There was no other family history of Gaucher's disease.

Because of the patient's thrombocytopenic bleeding attributable to hypersplenism, splenectomy was performed in December 1976 and this splenic material formed the basis of our study. Postoperatively, the patient has done well, and the pancytopenia has disappeared with cessation of the thrombocytopenic epistaxes.

\section{CYTOLOGY AND CYTOCHEMISTRY}

Bone marrow and splenic impression smears were examined by a variety of routine methods including polarised and ultraviolet microscopy, Romanowsky, PAS, acid and alkaline phosphatase, iron, peroxidase, Sudan black, $a$-naphthyl butyrate esterase with sodium fluoride inhibition, and naphthol AS-D chloroacetate esterase stains. Bone marrow and splenic material, fixed and processed in the manner 
described below, were also examined by electron microscopy.

PREPARATION OF CELL SUSPENSIONS

Splenic cells

A single cell suspension was obtained by forcing several pieces from different areas of freshly removed spleen through a 120 gauge stainless-steel mesh into a Hepes-buffered Hanks balanced salt solution (HBSS). The cell suspension was kept on ice until its return to the laboratory where the cells were washed in HBSS, and mononuclear cells were separated by centrifugation over Ficoll-Hypaque gradients (Böyum, 1968). The cells were washed a further three times in HBSS before being resuspended in HBSS $+0.2 \%$ bovine serum albumin (BSA) to a final concentration of $2 \times 10^{6} \mathrm{cells} / \mathrm{ml}$.

For comparison, suspensions from a 'normal' spleen (removed during gastrectomy for carcinoma of the stomach) and the spleen from a patient with hereditary spherocytosis (HS) were prepared in a similar way.

\section{Peripheral blood cells}

The patient's peripheral blood was examined on two occasions-initially, five days after splenectomy and, on a second occasion, 35 days post-splenectomy. On the latter occasion, the sister's blood was also examined. In each case, the blood was collected into heparin and the mononuclear cells were separated in the manner described above.

In both the splenic and the peripheral blood cell suspensions viability was assessed by the cells' ability to convert fluorescein diacetate to fluorescein (Celada and Rotman, 1967). Viability was greater than $95 \%$ in the peripheral blood, HS, and normal cell preparations. However, in the suspension from the Gaucher's spleen preparation the overall viability was $80 \%$, while the Gaucher's cells, which constituted approximately $30 \%$ of this preparation, showed some $50 \%$ viability, dead Gaucher's cells accounting for the great majority of the non-viable cells.

\section{ROSETTE TESTS}

\section{E-rosettes}

Sheep erythrocyte rosette tests (E) were carried out using aminoethylisothiouronium bromide-treated erythrocytes according to the method of Kaplan and Clark (1974).

\section{Fc-rosettes}

The method of Hallberg et al. (1973), using ox RBCs sensitised with rabbit anti-ox RBC IgG antibody, was employed. Unsensitised washed ox RBCs were used as an Fc control.

EAIgM-rosettes

Ox RBCs coated with rabbit anti-ox RBC IgM antibody (EA IgM) were used by a method previously described by us (Barker et al., 1976; Burns et al., 1977). This test also served as a control for the $C 3$ rosettes.

\section{C3-rosettes}

(a) C3bmo and C3dmo ${ }^{1}$ For C3bmo indicator cells, IgM-coated ox RBCs $(0.5 \mathrm{ml})$ were pre-warmed to $37^{\circ} \mathrm{C}$ and an equal volume of whole AKR mouse serum (1/10 dilution) was added. These were mixed for $70 \mathrm{~s}$ at $37^{\circ} \mathrm{C}$ and $5 \mu \mathrm{l}$ Antrypol(R) $(50 \mathrm{mg} / \mathrm{ml})$, which stabilises $\mathrm{C} 3 \mathrm{~b}$ against the action of KAF, was added and thoroughly mixed for 2 min (Lachmann et al., 1973).

As a source of C3dmo-coated cells, the reaction was allowed to proceed at $37^{\circ} \mathrm{C}$ without added Antrypol for 30 min during which time most $\mathrm{C} 3 \mathrm{~b}$ is converted to C3d by KAF.

(b) C3bhu and C3dhu ${ }^{2}$ These two types of indicator RBC were prepared in an identical way except that human serum previously exposed to zymosan $\left(\mathbf{R}_{3}\right.$ reagent) was used as the source of complement (McConnell and Hurd, 1976).

All the C3 rosette tests were performed by the method of Ross et al. (1973).

\section{Mouse (M-) rosettes}

The method of Gupta et al. (1976), using fresh, washed, unsensitised CBA mouse erythrocytes was employed.

In all rosette tests, the indicator RBCs were washed three times and resuspended to $1 \%$ in HBSS $+0.2 \%$ BSA before testing, and percentages of rosetting cells were assessed using the fluorescein diacetate method of Ramasamy (1974), scoring only the viable fluorescing cells under combined UV and phase contrast microscopy.

\section{SURFACE IMMUNOGLOBULIN (SMIG)}

An indirect method was employed which uses polyvalent rabbit anti-human gammaglobulin raised in the laboratory followed by fluoresceinated goat anti-rabbit IgG (Gibco Bio-Cult Ltd, Paisley, Scotland).

${ }^{1} \mathrm{C} 3 \mathrm{bmo}$ is the bound fragment of activated mouse complement component $\mathrm{C} 3$, and $\mathrm{C} 3 \mathrm{dmo}$ is the residual fragment of the inactivation of $\mathrm{C} 3 \mathrm{~b}$ by conglutinogen activating factor (KAF).

${ }^{2} \mathrm{C} 3 \mathrm{bhu}$ and $\mathrm{C} 3 \mathrm{dhu}$ are the corresponding human complement components. 


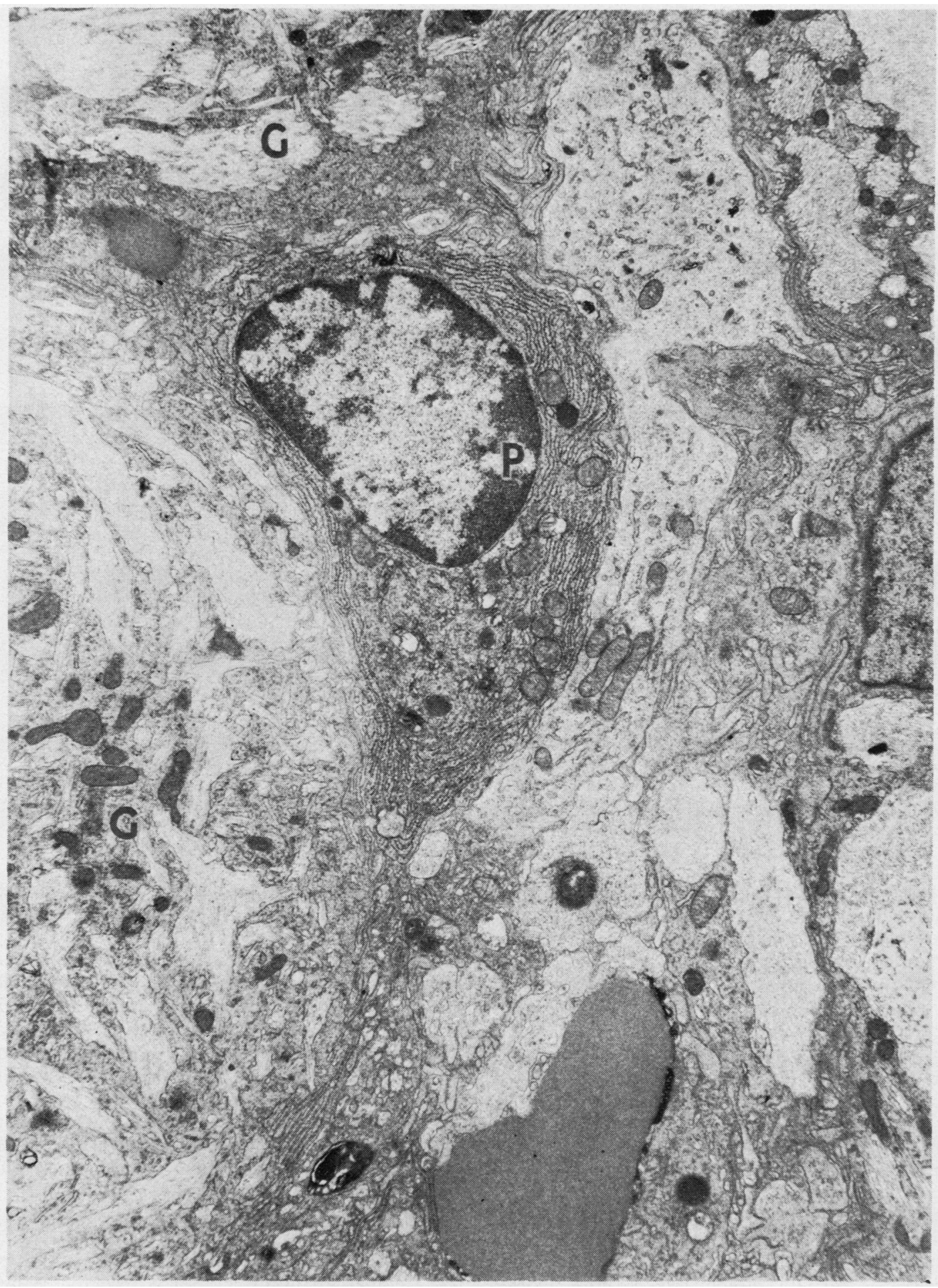

Fig. 1 EM of Gaucher spleen $(\times 8500)$. A mature plasma cell $(P)$ is seen to be intimately associated with two typical Gaucher's cells $(G)$. 


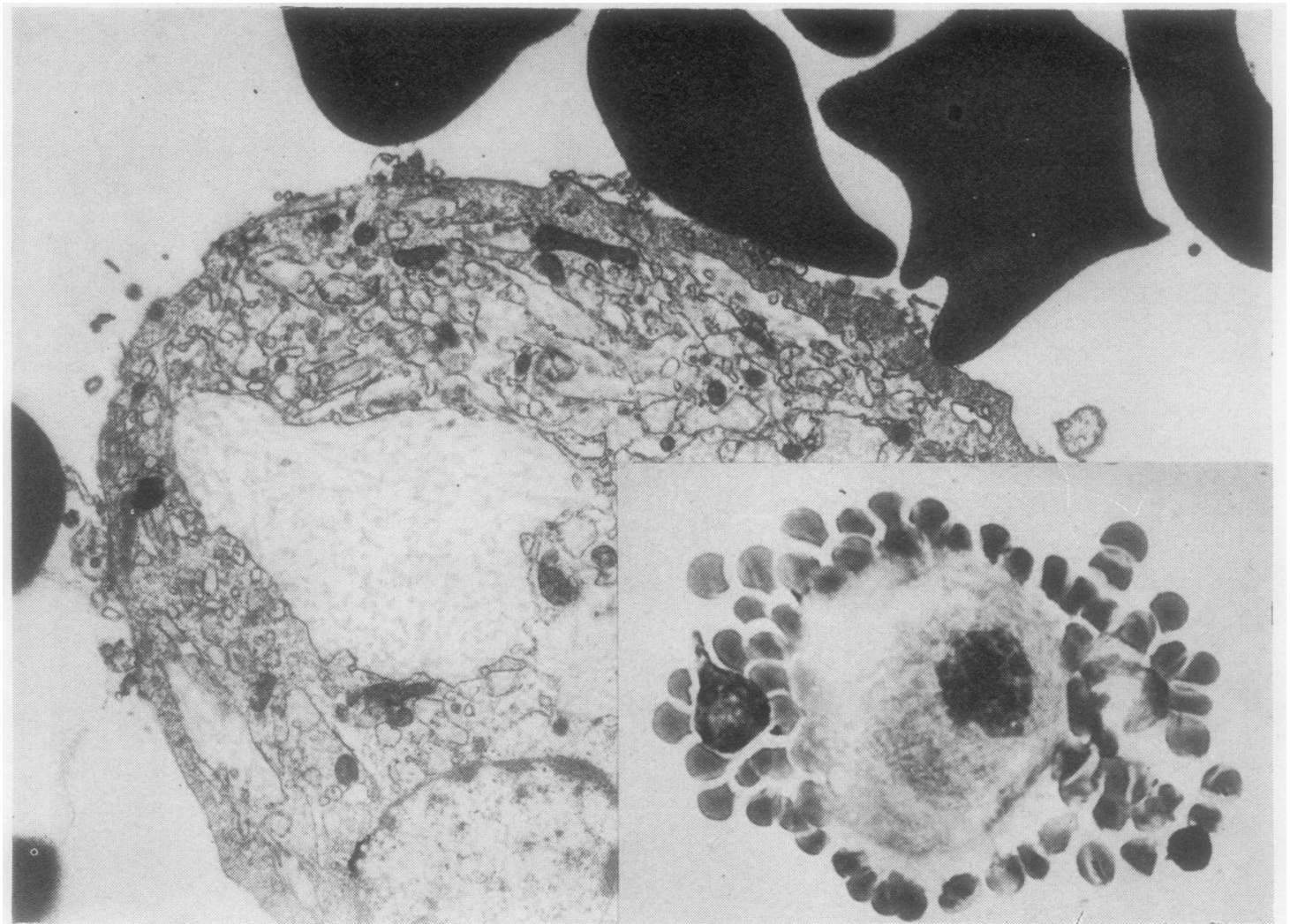

Fig. 2 Fc-rosettes preparation of splenic Gaucher's cell suspension. The ability of the Gaucher cell to form Fc-rosettes is well shown at the level of both the light (inset) and electron microscope. In the electron micrograph $(\times 12000)$ the Gaucher cell displays the imperfect fixation not infrequently observed in rosette preparations: this is presumably attributable to handling before fixation and was particularly marked in the case of the Gaucher cells.

The cytocentrifuge preparation (inset) shows the strong Fc-rosette typical of the intact Gaucher cells. The associated plasmacytoid cell on the left is also clearly seen to be forming an Fc-rosette.

\section{ELECTRON MICROSCOPY (EM)}

Bulk preparations of rosettes were formed by allowing $1 \mathrm{ml}$ of the splenic cell suspension at $2 \times$ $10^{6} / \mathrm{ml}$ to react with $1 \mathrm{ml}$ indicator erythrocytes. After centrifugation, the pellets were fixed in $3 \%$ glutaraldehyde and processed for EM by routine methods (Cawley and Hayhoe, 1973).

\section{Results}

\section{CYTOLOGY AND CYTOCHEMISTRY}

Both by light and electron microscopy, the large storage cells contained the striated inclusions which characterise Gaucher's disease (Figs 1 and 2). The cytochemistry was also typical of Gaucher's disease in showing strong PAS, acid phosphatase, and $\beta$-naphthyl butyrate esterase activity (Fig. 3a), which was partially inhibited by sodium fluoride.
The cells showed weaker alkaline phosphatase, iron, and naphthol AS-D chloroacetate esterase reactivity and were peroxidase and Sudan black negative.

Under polarised light the striated inclusions showed the form birefringence associated with some lipids (Bennett, 1950); in contrast, we have noted that the N inclusions of sea-blue histiocytosis are not birefringent (R. J. Flemans; unpublished observation). $N$ Under UV illumination, the Gaucher's cells did not $\underset{\omega}{N}$ autofluoresce, again in contrast to both the storage 0 cells of sea-blue histiocytosis and many bone 0 marrow reticuloendothelial cells in a variety of non- $\frac{\mathbb{\Phi}}{D}$ storage conditions which fluoresce a strong pink $\stackrel{\oplus}{+}$ (R. J. Flemans; unpublished observations).

\section{ROSETTE TESTS}

The results of the various splenic-cell rosette tests $\mathbb{D}$ are summarised in Table 1 . It is seen that a high $\underset{\frac{\sigma}{\sigma}}{\Omega}$

. 욱 


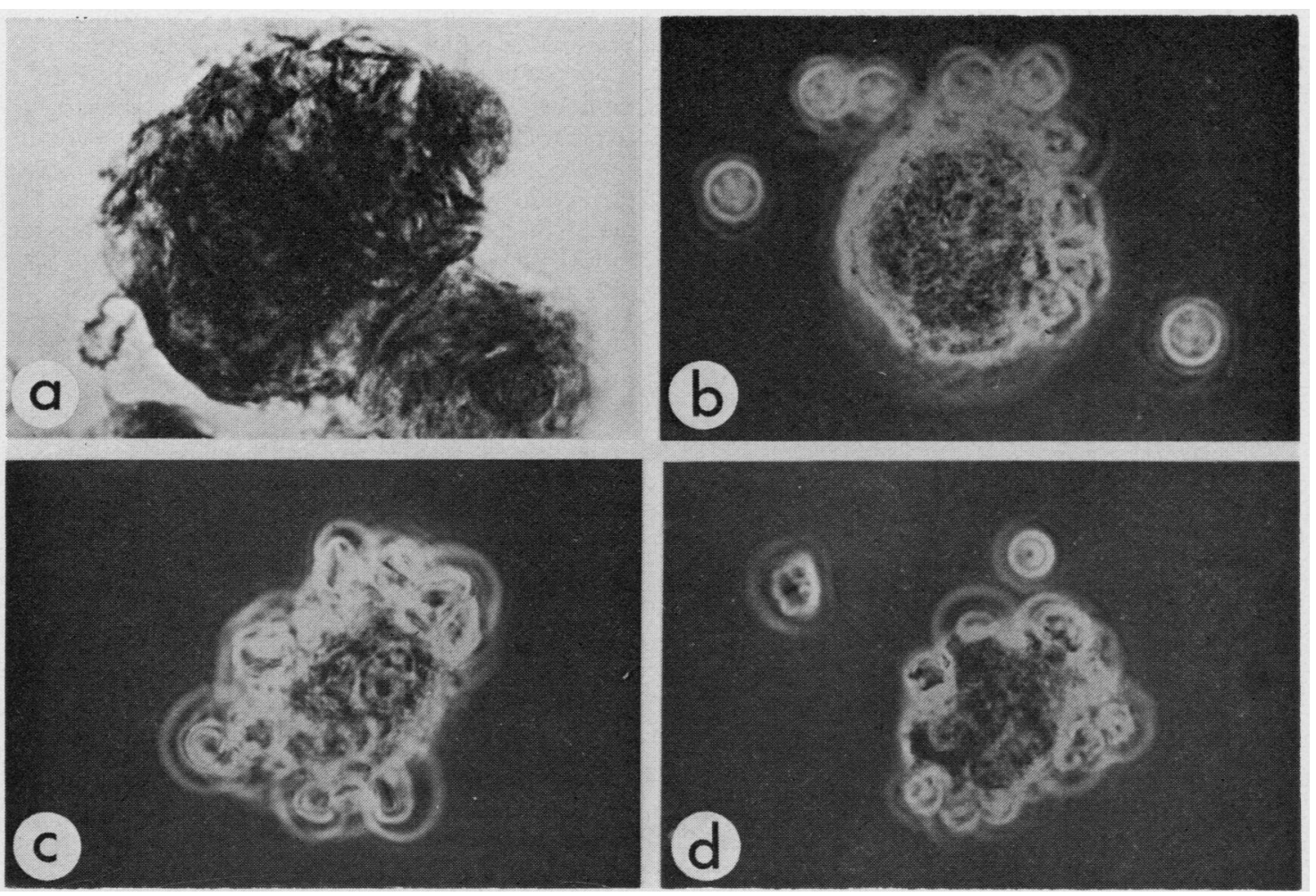

Fig. 3 Gaucher's cells. (a) a-naphthyl butyrate esterase preparation. The strong positivity of the Gaucher's cell is well shown. (b) E-rosette preparation; phase contrast, illumination. This positive rosette is typical in showing relatively few adherent sheep RBCs. (c) Fc-rosette formation; phase contrast illumination. This type of strong rosette with many adherent cells is typical. (d) Mouse erythrocyte-rosette formation; phase contrast illumination. The moderate number of adherent mouse RBCs in this example is typical. As is discussed in the text, this type of rosette, although definitely positive, tended to be less strong than the Fc rosette.

percentage of Gaucher's cells formed rosettes with unsensitised sheep (E) RBCs (Fig. 3b), and with ox indicator cells coated with either the $\mathrm{Fc}$ of IgG (Figs 2 and 3c) or with human $\mathrm{C} 3$ (both $\mathrm{C} 3 \mathrm{~b}$ and C3d). A high percentage of the Gaucher's cells also formed rosettes with unsensitised mouse (M) erythrocytes (Fig. 3d), while a much lower percentage formed rosettes with ox indicator cells coated with mouse $\mathrm{C} 3 \mathrm{~d}$. No rosette formation was seen with C3bmo-coated indicator cells. The $\mathrm{Fc}$ control (unsensitised ox RBCs) and the C3 control (EA $\mathrm{AgM}_{\text {Ig }}$ were also completely negative.

As is illustrated in Fig. 3 (b-d) the number of adherent indicator cells varied in the different rosette tests. Thus, in the $\mathrm{Fc}$ and $\mathrm{C} 3 \mathrm{hu}$ (not illustrated) rosettes, the large number of adherent RBCs probably indicates high receptor density. In contrast, most Gaucher's cells which formed rosettes with sheep RBCs had only four to five adherent RBCs, although a number had more than 10 adherent cells.
The mouse rosettes were of intermediate appearance, and this may indicate intermediate receptor density. It should be stressed that only viable cells were scored in all these rosette tests.

The percentage total spleen cells forming Erosettes in the Gaucher's preparation was remarkably low: indeed, none of the many small lymphocytes present was seen to form E-rosettes. This was in marked contrast to the findings in the two other spleens examined (Table 1).

The results of our studies in the T- and B-cell content of peripheral blood are summarised in Table 2 . In both the patient and her sister, the percentage of peripheral blood $\mathrm{T}$-cells appeared markedly reduced, whether estimated by E-rosette formation or by an esterase method recently described in this laboratory (Higgy et al., 1977).

In both the whole spleen tissue and the splenic cell suspension, the Gaucher's cells were frequently found to be closely associated with one or more 
Table 1 Rosetting properties of splenic cell suspensions

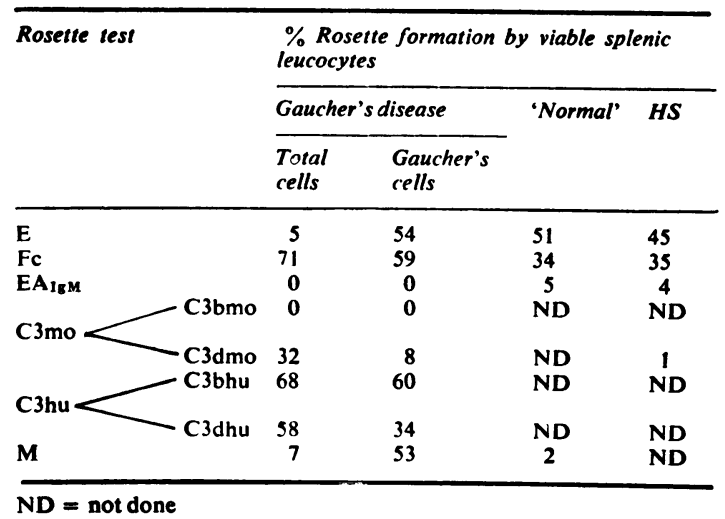

Table 2 Peripheral blood rosetting data

\begin{tabular}{llllll}
\hline Patient & \multicolumn{2}{c}{$\begin{array}{c}\% \text { Rosette formation } \\
\text { by mononuclear cells }\end{array}$} & & \multicolumn{2}{l}{ Esterase staining } \\
\cline { 2 - 3 } & $E$ & $F C$ & & $T$-cell & B-cell \\
\hline $\begin{array}{c}\text { Propositus 5 days } \\
\text { post-splenectomy }\end{array}$ & 24 & 44 & & 26 & 71 \\
$\begin{array}{c}\text { Propositus 35 days } \\
\text { post-splenectomy }\end{array}$ & 40 & 58 & & 45 & 34 \\
$\begin{array}{c}\text { Sister with Gaucher's } \\
\text { disease }\end{array}$ & 53 & 45 & & 54 & 35 \\
Normal 7-year-old girl & 71 & 24 & & ND & ND \\
\hline ND $=$ not done & & & & &
\end{tabular}

plasmacytoid cells (Figs 1 and 2 inset). These associated plasmacytoid cells formed strong $\mathrm{Fc}$ (Fig. 2 inset), and mouse, but no $\mathrm{C} 3$ or E rosettes.

SURFACE IMMUNOGLOBULIN

Whereas some small lymphocytes in the splenic cell preparation were positive for SmIg, both the Gaucher's cells and the associated plasmacytoid cells were uniformly negative for SmIg.

\section{Discussion}

The morphology of Gaucher's cells is so distorted by the accumulated glucocerebroside that firm conclusions about the basic nature of the cell are not possible at the level of either the light or electron microscopes. In addition, unlike typical marrow histiocytes, the Gaucher's cells do not autofluoresce under UV light. However, our cytochemical studies, like those of others (Rozenszajn and Efrati, 1961), are consistent with the assumed monocytic origin of these cells; in this regard, the $\alpha$-naphthyl butyrate esterase positivity, inhibited by sodium fluoride, is particularly suggestive of a monocytic origin.

Our demonstration of strong Fc-rosette formation by Gaucher's cells, in the absence of SmIg, is also in keeping with a monocyte/histiocyte nature. The presence of a high density of receptor for human C3 (both C3b and C3d) is again in accord with a monocytic/histiocytic origin of the Gaucher cell (Ross and Polley, 1975). The failure to form C3bmo rosettes, and only a low percentage of rosette formation with $\mathrm{C} 3 \mathrm{dmo}$, is difficult to interpret but may reflect either a lower density of $\mathrm{C} 3$ products on those indicator cells or the ability of the Gaucher's cells to distinguish between human and mouse $\mathrm{C} 3$. The ability of Gaucher's cells to form rosettes with sheep erythrocytes is also difficult to interpret. Normally, E-rosettes formed by T-lymphocytes of less than $10 \mu$ diameter consist of a tight morula made up of several layers of indicator cells. In contrast, the much larger Gaucher's cells ( $>40 \mu$ diameter) usually displayed only relatively few adherent cells sparsely distributed over the cell surface. Although it is possible that Gaucher's cells possess a receptor similar to that of T-lymphocytes, in view of the other characteristics of the cells, it is difficult to imagine that the formation of rosettes with sheep RBCs is a true expression of a T-lymphocyte phenotype. Histiocytes are known to be capable of recognising and removing effete erythrocytes, and the rosettes seen with sheep RBCs may be related to this process. Some support is lent to this interpretation by our observation of weak E-rosette formation by the storage cells of a single case of sea-blue histiocytosis (Burns, unpublished observations). Because the mouse rosette test is generally considered to identify specifically a subpopulation of B-lymphocytes (Forbes and Zalewski, 1976) and the leukaemic cells in CLL (Stathopoulos and Elliott, 1974), the reactivity of the Gaucher's cell may also be attributed to the adherence of effete RBCs. However, in our hands, some normal monocytes and neutrophils form M-rosettes, and thus the ability of Gaucher's cells to form these rosettes may be fully compatible with a monocyte-histiocyte lineage.

In view of the immunological abnormalities that may be associated with Gaucher's disease (Pratt et al., 1968), the severe deficiency of splenic T-cells demonstrated by the strikingly low percentage of E-rosette formation by the numerous lymphocytes present in the patient's spleen is of interest. This deficiency is clearly not attributable to sampling error since our splenic suspension was prepared from several pieces of tissue from widely different areas of the spleen. This unexpected finding prompted us to examine the T-cell content of the patient's peripheral blood. Interestingly, both the patient and her sister displayed a definite reduction in the percentage of circulating T-cells. These results cannot be simply attributed to a defect in our 
E-rosette technique because it yielded an entirely normal result in a control child and because similar results were obtained by a completely different method employing esterase cytochemistry (Higgy et al., 1977). Furthermore, the detection of T-lymphopenia in the sister argues against the finding in this patient being simply a response to the operation and/or its attendant anaesthetic. The possibility that the $\mathrm{T}$-lymphopenia represents a manifestation of hypersplenism or an unrelated chance association cannot, however, be excluded.

The association between plasma cells and both normal reticuloendothelial cells and Gaucher's cells is well recognised, and the latter observation is confirmed in the present study. However, since the associated cells closely resembled mature plasma cells morphologically, and lacked SmIg, the presence of an Fc receptor on their surface is an unusual finding since plasma cells usually lack the Fc receptor (McConnell, 1975). We are unable to offer any definitive explanation for this finding. However, it has been suggested that plasma cells actively secreting immunoglobulin lack the $F c$ receptor while inactive plasma cells possess this marker (Ramasamy et al., 1974); the Gaucher-associated plasma cells may therefore be inactive cells.

To conclude, the present marker study largely substantiates the assumed relationship between Gaucher's cells and cells of the monocyte/histiocyte series. However, some possible differences between Gaucher's and monocytoid cells were observed, but their significance awaits further investigations of both more cases of Gaucher's disease and the surface marker properties of the reticuloendothelial cells of normal spleen, for which no data are currently available. Moreover, the demonstration of an apparent T-cell deficiency in the present patient's spleen and peripheral blood suggests that examination of T-cell function in further cases of Gaucher's disease should be undertaken.

It is a pleasure to acknowledge the help and cooperation of Professor R. W. Smithells and Mr J. M. Beck, of Leeds General Infirmary, and Dr R. J. M. Bell, of Scunthorpe General Hospital, all of whom assisted us in studying this family under their care. We are grateful to $\mathrm{Mr}$ G. Binns for technical assistance.

GFB and KEH gratefully acknowledge support from the Medical Research Council (UK) and the government of the United Arab Republic of Egypt respectively.

\section{References}

Barker, C. R., Burns, G. F., Cawley, J. C., and Hayhoe,
F. G. J. (1976). IgM receptors on the surface of hairy cells of leukaemic reticuloendotheliosis (Letter). Lancet, 1, 1303.

Bennett, H. S. (1950). The microscopical investigation of biological materials with polarized light. In McClung's Handbook of Microscopical Technique, 3rd edition, edited by $\mathbf{R}$. McClung Jones, pp. 591-677. Hoeber, New York.

Böyum, A. (1968). A one-stage procedure for isolation of granulocytes and lymphocytes from human blood. Scandinavian Journal of Clinical and Laboratory Investigation, 21, Supplement 97, 51-76.

Brady, R. O. (1972). Biochemical and metabolic basis of familial sphingolipidoses. Seminars in Haematology, 9, 273-284.

Burns, G. F., Cawley, J. C, Barker, C. R., Goldstone, A. H., and Hayhoe, F. G. J. (1977). New evidence relating to the nature and origin of the hairy cell of leukaemic reticuloendotheliosis. British Journal of Haematology, 36, 71-84.

Cawley, J. C. and Hayhoe, F. G. J. (1973). Ultrastructure of Haemic Cells. W. B. Saunders, London.

Celada, F. and Rotman, B. (1967). A fluorochromatic test for immunocytotoxicity against tumor cells and leucocytes in agarose plates. Proceedings of the National Academy of Sciences, 57, 630-636.

Fisher, E. R. and Reidbord, H. (1962). Gaucher's disease: pathogenetic considerations based on electron microscopic and histochemical observations. American Journal of Pathology, 41, 679-691.

Forbes, I. J. and Zalewski, P. D. (1976). A subpopulation of human B lymphocytes that rosette with mouse erythrocytes. Clinical and Experimental Immunology, 26, 99-107.

Gupta, S., Good, R. A., and Siegal, F. P. (1976). Rosetteformation with mouse erythrocytes. II. A marker for human B and non-T lymphocytes. Clinical and Experimental Immunology, 25, 319-327.

Hallberg, T., Gurner, B. W., and Coombs, R. R. A. (1973). Opsonic adherence of sensitized ox red cells to human lymphocytes as measured by rosette formation. International Archives of Allergy, 44, 500-513.

Higgy, K. E., Burns, G. F., and Hayhoe, F. G. J. (1977). Discrimination of $B, T$ and null lymphocytes by esterase cytochemistry. Scandinavian Journal of Haematology, 18, 437-448.

Kaplan, M. E. and Clark, C. (1974). An improved rosetting assay for detection of human $\mathrm{T}$ lymphocytes. Journal of Immunological Methods, 5, 131-135.

Lachmann, P. J., Hobart, M. H., and Aston, W. P. (1973). Complement technology. In Handbook of Experimental Immunology, 2nd edition, edited by D. M. Weir. Blackwell, Oxford.

Lee, R. E., Balcerzak, S. P., and Westerman, M. P. (1967). Gaucher's disease. A morphologic study and measurements of iron metabolism. American Journal of Medicine, 42, 891-898.

McConnell, I. (1975). T and B lymphocytes. In The Immune System, edited by M. J. Hobart and I. McConnell, p. 98. Blackwell, Oxford.

McConnell, I. and Hurd, C. M. (1976). Lymphocyte receptors. II. Receptors for rabbit IgM on human $\mathbf{T}$ 
lymphocytes. Immunology, 30, 835-839.

Pennelli, N., Scaravilli, F., and Zacchello, F. (1969). The morphogenesis of Gaucher cells investigated by electron microscopy. Blood, 34, 331-347.

Pratt, P. W., Estren, S., and Kochwa, S. (1968). Immunoglobulin abnormalities in Gaucher's disease. Report of 16 cases. Blood, 31, 633-640.

Ramasamy, R. (1974). A fluorescent stain for viable rosette-forming cells. Journal of Immunological Methods, 5, 305-306.

Ramasamy, R., Munro, A., and Milstein, C. (1974). Possible role for the $\mathrm{Fc}$ receptor on B lymphocytes. Nature, 249, 573-574.

Roos, B., Cottier, H., and Rossi, E. (1961). Electronoptical observations in storage diseases (Abstract). Experientia, 17, 430.
Ross, G. D., Rabellino, E. M., Polley, M. J., and Grey, H. M. (1973). Combined studies of complement receptor and surface immunoglobulin-bearing cells and sheep erythrocyte rosette-forming cells in normal and leukemic human lymphocytes. Journal of Clinical Investigation, 52, 377-385.

Ross, G. D. and Polley, M. J. (1975). Specificity of human lymphocyte complement receptors. Journal of Experimental Medicine, 141, 1163-1180.

Rozenszajn, L. and Efrati, P. (1961). Cytochemical and phase-contrast observations on Gaucher cells. Acta Haematologica, 25, 43-48.

Stathopoulos, G. and Elliott, E. V. (1974). Formation of mouse or sheep red-blood-cell rosettes by lymphocytes from normal and leukaemic individuals. Lancet, 1, 600-601. 